\title{
「企業実践講座」「プチ・インターンシップ」 等を通した地元に貢献する技術者養成
}

Education of Engineers Who Contribute Local Industry through “Corporate Practice”, "Petit Internship" and "Local Industry Fair"

藤 本晶 ${ }^{*} 1$ Akira FUJIMOTO

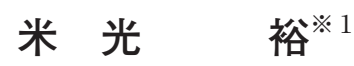

Hiroshi YONEMITSU
高 木 浩 一 ${ }^{* 1}$ Koichi TAKAGI

\section{田中勇 次 ${ }^{* 1}$}

Yuji TANAKA

\section{1.はじめに}

和歌山県は高等教育機関の少ない県で，高校生の県 外の大学への進学率も過去 20 年以上全国一を続けてい る ${ }^{1)}$ ，そのことを反映して県の人口も若者を中心に減 少を続け，平成 22 年には近畿の府県では初めて 100 万 人を割り达むに至った ${ }^{2), 3)}$. 和歌山県も人口減少に危 機感を持ち, 県外に流出した人のUターンを促進する 施策を続けている.

和歌山県中部に位置する和歌山高専は，卒業時点で 就職する学生と進学する学生がほぼ半々の, 平均的な 高専である. 学生の 9 割弱は地元和歌山県内の出身者 で，県内の貴重な高等教育機関となっているが，卒業 時に県内企業へ就職する学生は, 就職希望者の 2 割, 全体の 1 割程度に過ぎない。地元で中学生を集めて県 外に送り出している実態から, 和歌山高専も和歌山県 の人口減少に加担していることがわかる.

多くの卒業生が県外に出て行く一因として, 和歌山 県内にはテレビ等を通じて学生の目に触れることの多 い有名大企業が少ないことがあげられる，学生が県内 の中小企業に魅力を感じないこと以外に, 県内の企業 の存在そのものを知らないこともある. 県内の中小企 業にも他にはない，キラリと光る技術を持っていると ころも少なくない ${ }^{4)}$.

そこで学生に県内企業を知って貴い, 県内企業を就 職先の選択肢に入れて貫いたい，そのような願いを込 めて和歌山高専では(1)県内企業トップを講師に招く 「企業実践講座」, (2)県内企業が一同に会して学生に説 明する「県内企業合同説明会」, (3)低学年から県内企 業に出向く「プチ・インターンシップ」の 3 つの施策 を行っている.

これらの施策の目的は主に県内企業への就職促進で あったが, 学生に卒業後の自らの進路や将来のイメー ジを考えさせる良い機会となっており, 和歌山高専の キャリア教育の一翼を担っている。ここでは和歌山高

2011 年 9 月 16 日受付

※ 1 和歌山工業高等専門学校
専が取り組んでいるこれらの施策を紹介する.

\section{2. 取り組んだ施策}

ここで紹介する 3 つの施策は, 県内企業への就職促 進をキーワードに害施してきた。しかしそれぞれの きっかけや，実施形態はそれぞれ異なっている，以下 にそれぞれの取り組みの経緯と取り組み内容を述べ る.

\section{1 企業実践講座}

この講座は, 和歌山県から「地元企業を学生に知っ て貴うため, 地元企業のトップが定期的に, 学生に直 接講演できる機会を作って欲しい.」という申し入れ がきっかけで実現した事業である。当初は自由に参加 できる「講演会」を強くイメージされた提案であった が, 自由参加では学生が集まる保証が無いこと, でき るだけ多くの学生に周知するには「授業」の形を取る 必要があること等を申し入れて話し合いを続けた。約 1 年余の話し合いの結果,

(1)形態は「授業」とすること.

(2)受講者は第 4 学年で, 全学科の学生が受講できる こと.

(3)特定の企業に偏ることなく, 多数の企業の方を講 師に招くこと.

(4)毎回テーマを決めて, それに沿って進めること.

(5)適切に評価するために, 聴講学生には毎回レポー トを提出させること．

等に留意して進めることになった（1)のためにはシラ バスの準備, 講師の選定, 評価方法の明確化が必要と なる. (2)は就職を間近に控えた学年として第 4 学年と し,特定の業種に偏らないためにも全学科対象とした. (3)のためには講師予定者を訪問して, 授業の趣旨を伝 え, 理解を得ること. (4)ではテーマに合った講師の人 選をすること, そして(5)ではレポートの趣旨を学生に 説明し，採点基準を作ること等が必要となった。

これらの準備を行って平成21年度から第 4 学年の選 択科目として実施することができた. 当初は講師の方 の採点の負荷を考慮して, 定員を60名として受講者を 
表 1 平成 22 年度の企業実践講座の授業スケジュール

\begin{tabular}{|c|c|c|c|}
\hline 開催日 & - & 講 & \\
\hline $\begin{array}{c}\text { 【第 } 1 \text { 回】 } \\
\text { 10月 } 6 \text { 日(水) }\end{array}$ & 和歌山県の現状, 地元企業の概要 & $\begin{array}{l}\text { 和歌山県商工観光労働部 } \\
\text { 企業政策局企業立地課長 }\end{array}$ & 児玉征也 \\
\hline $\begin{array}{c}\text { 【第 } 2 \text { 回】 } \\
\text { 10月13日(水) }\end{array}$ & 企業活動の概要（企業理念・公器性） & $\begin{array}{l}\text { 中野 B C 株式会社 } \\
\text { 代表取締役社長 }\end{array}$ & 中野幸生 \\
\hline $\begin{array}{c}\text { 【第 } 3 \text { 回】 } \\
\text { 10月20日(水) }\end{array}$ & 企業組織の概要（取締役会，事業部制，部課制等） & $\begin{array}{l}\text { 協和プレス工業株式会社 } \\
\text { 代表取締役社長 }\end{array}$ & 野村壮吾 \\
\hline $\begin{array}{c}\text { 【第 } 4 \text { 回】 } \\
\text { 10月27日(水) }\end{array}$ & 社会人としての常識, マナー & $\begin{array}{l}\text { 株式会社サンコー } \\
\text { 取締役相談役 }\end{array}$ & 角谷勝司 \\
\hline $\begin{array}{c}\text { 【第 } 5 \text { 回】 } \\
\text { 11月10日(水) }\end{array}$ & 製品開発の手法と実際（I ） & $\begin{array}{l}\text { 株式会社紀州ほそ川 } \\
\text { 代表取締役社長 }\end{array}$ & $\begin{array}{l}\text { 細川 清 } \\
\text { 切目安昭 }\end{array}$ \\
\hline $\begin{array}{c}\text { 【第 } 6 \text { 回】 } \\
\text { 11月17日(水) }\end{array}$ & 製品開発の手法と実際（II） & $\begin{array}{l}\text { 太洋工業株式会社 } \\
\text { 研究開発部次長 }\end{array}$ & 浅井賴明 \\
\hline $\begin{array}{c}\text { 【第 } 7 \text { 回】 } \\
\text { 11月24日(水) }\end{array}$ & 工場生産の実際 & $\begin{array}{l}\text { 紀州技研工業株式会社 } \\
\text { 専務取締役 }\end{array}$ & 釜中眞次 \\
\hline $\begin{array}{c}\text { 【第 } 8 \text { 回】 } \\
\text { 12月 } 1 \text { 日(水) }\end{array}$ & 品質保証の実際（ I ） & $\begin{array}{l}\text { 築野食品工業株式会社 } \\
\text { 研究統括責任者 }\end{array}$ & 橋本博之 \\
\hline $\begin{array}{c}\text { 【第 } 9 \text { 回】 } \\
\text { 12月15日(水) }\end{array}$ & 品質保証の実際（II） & $\begin{array}{l}\text { 大洋化学株式会社 } \\
\text { 品質管理室グループリーダー }\end{array}$ & 後藤和良 \\
\hline $\begin{array}{c}\text { 【第10回】 } \\
\text { 12月22日(水) }\end{array}$ & 物流と販売の実際 & $\begin{array}{l}\text { 株式会社島精機製作所 } \\
\text { 物流部物流グループ課長代理 }\end{array}$ & 松本昌士 \\
\hline $\begin{array}{c}\text { 【第11回】 } \\
1 \text { 月12日(水) }\end{array}$ & 財務管理の概要（I ）, 簿記の必要性, 簿記の概要 & $\begin{array}{l}\text { 株式会社紀陽銀行 } \\
\text { 融資部部長代理 }\end{array}$ & 山東弘之 \\
\hline $\begin{array}{c}\text { 【第12回】 } \\
1 \text { 月19日(水) }\end{array}$ & 財務管理の概要（II ), 財務諸表の読み方見方 & $\begin{array}{l}\text { 株式会社紀陽銀行 } \\
\text { 融資部部長代理 }\end{array}$ & 山東弘之 \\
\hline $\begin{array}{c}\text { 【第13回】 } \\
1 \text { 月26日(水) }\end{array}$ & 企業の社会的責任, リスクマネジメント & $\begin{array}{l}\text { 株式会社紀陽銀行 } \\
\text { リスク統括部長 }\end{array}$ & 葉系正浩 \\
\hline $\begin{array}{c}\text { 【第14回】 } \\
2 \text { 月 } 2 \text { 日(水) }\end{array}$ & 起業するには（資金, 従業員, 届け出等） & $\begin{array}{l}\text { 株式会社エスアールアイ } \\
\text { 代表取締役社長 }\end{array}$ & 浦 聖治 \\
\hline $\begin{array}{c}\text { 【第15回】 } \\
2 \text { 月 } 9 \text { 日(水) }\end{array}$ & まとめ & $\begin{array}{l}\text { 和歌山工業高等専門学校 } \\
\text { 電気情報工学科 教授 }\end{array}$ & 藤本 晶 \\
\hline
\end{tabular}

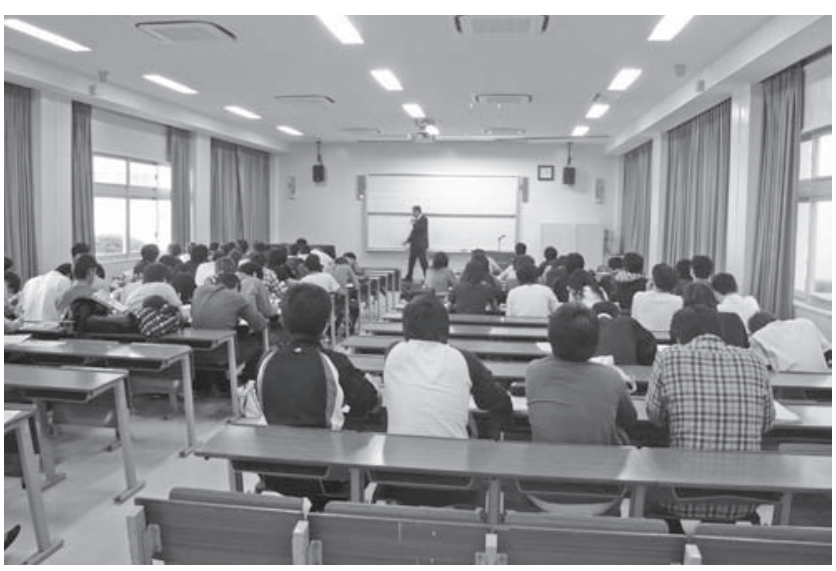

図 1 県内企業トップの話を聞く

(平成22年度企業実践講座にて)

募集したところ，第 4 学年160名の内，140名が受講を 希望してきた。そのため授業の趣旨を説明し, 辞退者 を募ったが, 辞退を申し出たのが数名に留まったので, やむなく抽選で60名に絞り込んだ。 1 年の実施を経て 講師の方の意見も参考にして, 受講希望者が多いこと に留意して翌年は定員を 80 名に，そして平成 23 年度は

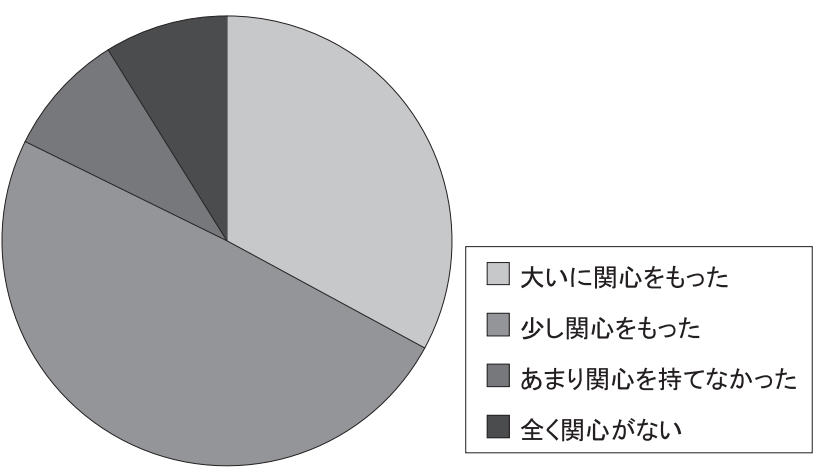

図 2 企業実践講座修了後の学生アンケート結果

100名にまで枠を広げた。

2 年目となる平成 22 年度の授業スケジュールを表 1 に示す，授業では，各企業の経営や技術のトップもし くはトップに近い方が, 企業の理念や企業で働く際の 心構え等を, 自らの経験に基づいて分かり易く説明し ている. 授業に対する学生の評判も上々で, 受講生の 9 割が 1 回も休まずに出席し, 熱心に聞いていた（図 1). また授業終了後のアンケートでも, 約 8 割の学 生が地元企業に大いに, あるいは少し関心を持ったと 


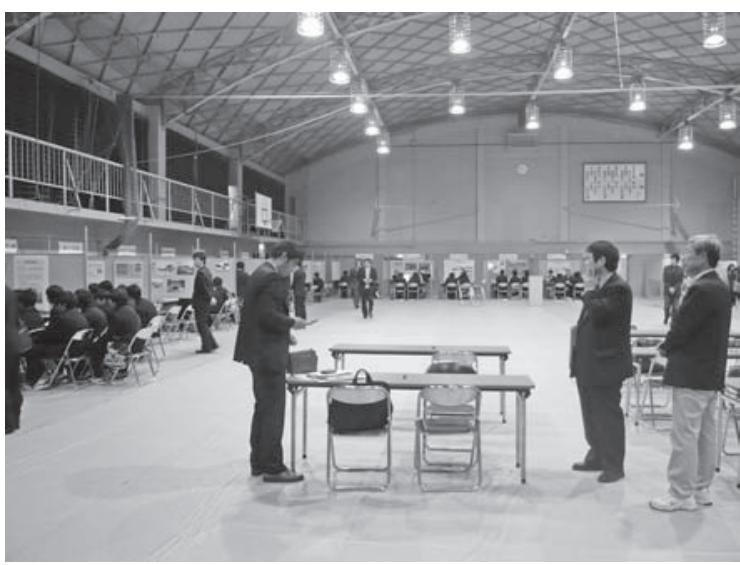

体育館での県内企業合同説明会

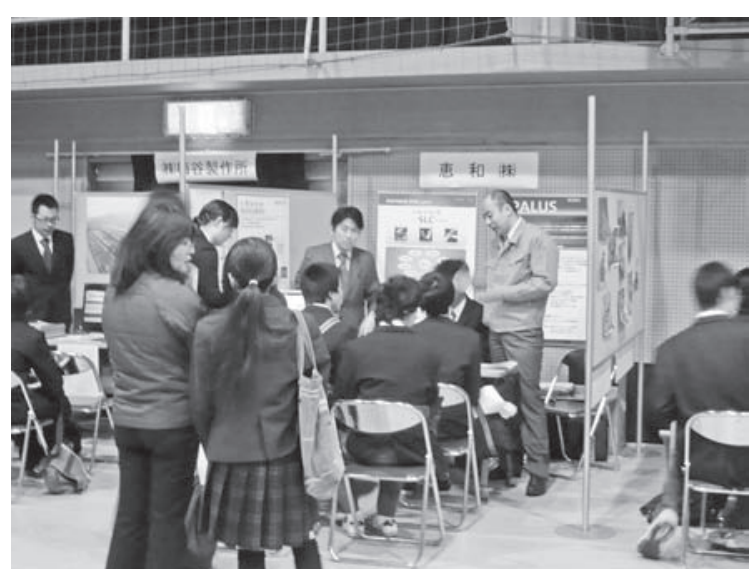

県内企業合同説明会のブースで説明を聞く

図 3 県内企業合同説明会の様子

答えており，授業の当初の目的は達したものと考える (図 2 ).

\section{2 県内企業合同説明会}

この事業は, 和歌山県の地元銀行である「紀陽銀行」 の提案で平成 20 年度から実施している。背景には, 卒 業生に地元に残って貫い, 地元の発展に尽力して貪い たいという希望に加えて，地元企業からの「和歌山高 専からインターンシップ受け入れの依頼はくるが, 求 人を出しても学生を送って貴えない.」といった声が あるものと考える。

事業の実施に際しては，(1)和歌山高専を会場にして 県内企業に集まって貫う, (2)就職希望者のみならず, 進学希望者も参加してもらう, (3)参加企業は紀陽銀行 が選ぶ，(4)和歌山県の現状や就職に当たっての心構え 等についての講演会を実施する，等に留意した。(1)は 和歌山高専で行うことで多数の学生の参加を促すこ と, (2)に際しては昨今進学希望者が増加していること と, 大学卒業後に和歌山県に戻って来て欲しいという 願いを込めて, (3)中小企業の多い和歌山県において, その経営状態等，学校関係者からは見えにくい部分を 考慮して貫うこと，そして(4)は就職講座の意味合いを 达めて講演会を併設することにしている。このような 準備の下で平成 20 年度に県内企業 38 社の参加の下に第 一回「県内企業合同説明会」を実施した ${ }^{5}$ (図 3 ).

実施にあたっては，第 4 学年学生の全員参加の行事 とし, 各人が最低 3 社のブースを回ることや事後のア ンケートに答えること等を義務づけた，参加した学生 の中には, 最初から県内企業に関心が無いといった者 もいたが，多くの学生は「県内にこんなに企業がある とは知らなかった.」といった感想を述べており，こ の施策についても県内企業を知って貫うという当初の 目的は達したものと考える. アンケート結果でも参加 者の 9 割の学生が, 魅力ある企業を見つけたと答えて おり（図 4 ），実際にその場で就職を決心した学生も 数名現れた.

また参加企業の評判も上々で, アンケート結果から

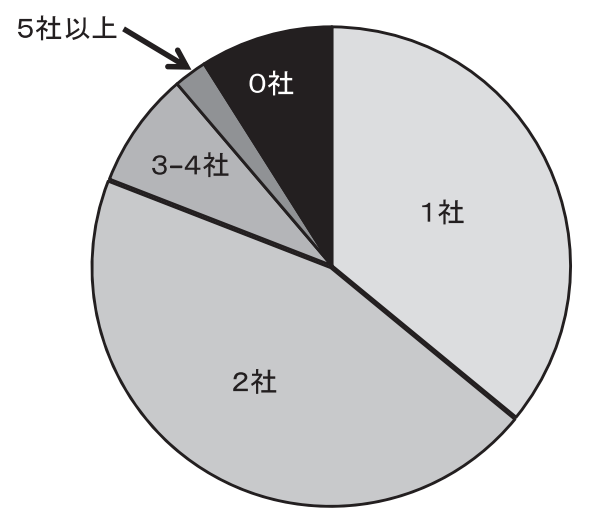

図 4 県内企業合同説明会で見つけた魅力ある企業数 (学生アンケートより)

は参加38社すべてがこの説明会は有意義であったと回 答し， 7 割の企業が参加した学生に満足していると答 えている.多少甘めの回答が多いことを差し引いても， 県内企業が高専卒業生に熱い視線を送っていることは 間違いないであろう．翌年もこの説明会に参加すると 答えた企業が 7 割に上っていることも，このことを裏 付けているものと考える。

なお平成21年度には全国中小企業団体中央会の援助 を基に, 近隣の紀央館高等学校と田辺工業高等学校の 2 校の生徒にも, そして 22 年度には更に紀北工業高等 学校と和歌山工業高等学校の 2 校の生徒にも参加して 貴っている ${ }^{6)}$.

\section{3 プチ・インターンシップ}

この取り組みは全国中小企業団体中央会が実施して いる「ものづくり分野の人材育成・確保事業」の一環 として行ったものである. 事業の趣旨は, 中小企業の 支援であり, 中小企業の比率が全国一である和歌山県 においては, 地元企業への就職支援がそのまま中小企 業の支援に繋がるとの考えから事業を進めた.

事業の柱は普段はインターンシップを経験しない低 学年の学生を地元企業に連れて行き, 現場の技術者か ら直接話を聞いたり，製品に触れたりする「プチ・イ ンターンシップ」と称した工場見学である。参加した 


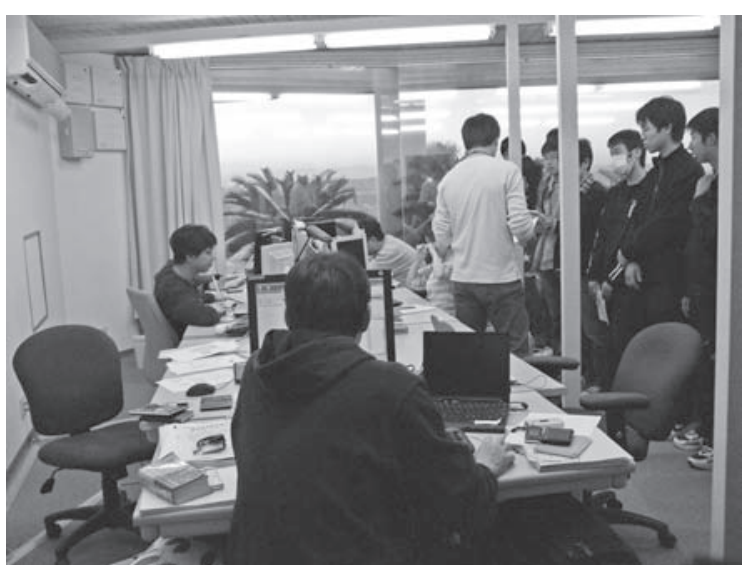

IT 関連の製品開発の現場を見学する

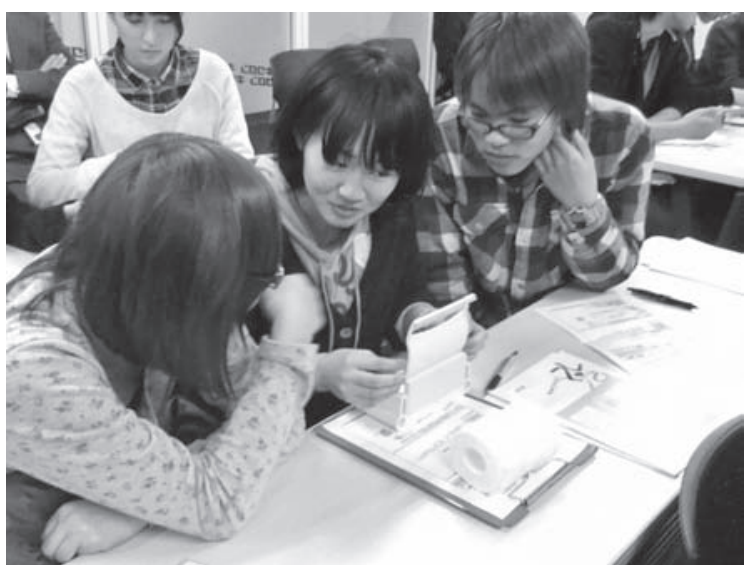

企業に出向いて製品について学ぶ

図 5 プチ・インターンシップ先での様子

のは全学科の第 1 学年から第 3 学年までの計 12 クラス 480名である。実施に際しては学級担任と各学科主任 とで予め訪問先企業を選定し, 訪問日程の調整を行っ た，訪問は貸し切りバスを利用し，キャリア教育の一 環との位置づけから，主にホームルームの時間を使っ て行った.

訪問先には予め施策の目的や訪問時に留意して欲し い事柄等を伝えた。訪問では最初に企業の概要説明を 聞いた後, 開発の現場を訪れ, 開発担当の技術者から 直接製品の説明や，現在開発中の製品の技術課題等の 説明を受けたり，実際に開発中の製品に触れたりと， 通常の工場見学から一歩踏み出した施策とした（図 5 ).

平成 21 年と 22 年の 2 年間ホームルームの時間を使っ てプチ・インターンシップを実施したが，時間的にも， またホームルームのスケジュール的にも余裕が無かっ たこともあり, 参加した学生の評判は必ずしも芳しい ものでは無かった。低学年でまだ進路に関心が低いこ とも一因かも知れないが，中には「大変役に立った」 と答える学生もおり, 学生個々の意識の差が感想に反 映しているものと考える。プチ・インターンシップ実 施前後でのアンケート結果からも，地元企業に関心が あると答えた学生は, 実施前が148名, 実施後が149名 とほとんど変わらなかった．低学年を対象としたこの ような施策の効果を上げるには, 取り組みの意義や目 的を丁寧に説明する等, 事前の動機付けや学習, それ に加えて実施方法や現地での説明，体験内容等につい ての工夫が必要だと考える.

\section{3. 終わりに}

地元企業から多くの求人があるにも関わらず，就職 先の選択肢に地元企業が入っていない.このような現 状を少しでも改善すべく, 企業実践講座, 県内企業合 同説明会, そしてプチ・インターンシップの 3 つの施 策を実施した，企業実践講座を開始した翌年は，それ まで20名前後で推移していた地元企業への就職者が,
27名へと増加した。しかしその翌年には，またもとの 水準に戻ってしまうなど，まだ安定した成果は出てい ない。このような施策の評価は，もう少し長い目で見 る必要があると考える。

学生が企業への関心を高めることは, 自らの将来像 を描くことの一助になることに加え, 普段学習してい る内容が社会でどのように役立つのかを知ることにも 慗がる，将来役立つことが目に見える形で理解できれ ば, 学習への極めて強い動機付けになると考える. 高 専生が苦手とされる英語に抏いても, その大切さを企 業の現場の技術者から聞かされることで, 学習意欲が 湧くであろう.

また学習面だけでなく, 企業での規律, 身だしなみ, 挨拶などの社会常識も，将来自らが身を置くであろう 職場の状況を目の当たりにすることで, 自然な形で身 について行くものと考える. 高専の特色の一つに挙げ られているインターンシップは, そのための絶好の機 会である. 昨今では一般大学や普通科高等学校でもイ ンターンシップの重要性が叫ばれ, 実施されつつある. インターンシップの先駆者である高専においては，そ の先を行く取り組みが必要になると考える。

和歌山高専は毎年160名の卒業生を輩出し，その内 の半数強が就職する. 就職希望者全員が地元に残る必 要は無いが, 全体の 9 割の学生が地元出身であること を考えると, 現状就職希望者の 2 割, 卒業生全員の 1 割しか地元に残らないのは, やはり少ないと感じてい る. 優秀な人材の供給が, 地元企業への最大の貢献で あり, 高専の使命の一つであることを考えると, 卒業 生が地元企業にも関心を持つ機会を増やす必要性を感 じている.ここで紹介した取り組み等を通じて, 今後 とも地元企業への関心を高めるための模索を続ける所 存である.

\section{謝辞}

ここで紹介した施策のうち, 企業実践講座の実施に あたっては和歌山県労働政策課様の, 県内企業合同説 
明会の実施にあたっては株式会社紀陽銀行様の，そし てプチ・インターンシップの実施では全国中小企業団 体中央会様からの甚大なご援助をいただきました，関 係各位に対し，紙面を借りてお礼申し上げます。

\section{参 考 文 献}

1) 和歌山県企画部企画政策局調查統計課：平成22 年度 指標からみた和歌山県のすがたー県勢編 -, p.119, 平成 22 年 10 月

2 ) 朝日新聞夕刊大阪版: 和歌山県 100 万人割れ 若者 減り近畿で唯一, 2010年 8 月 30 日

3 ）紀伊民報：県人口 15 年連続で減少, 平成 23 年 5 月 7 日

4 ）中小企業庁編：2006年度版 元気なモノ作り企業 300 社
5 ）産経新聞記事：技術力ある学生「ぜひ県内企業 へ」, 平成20年12月13日

6 ）文教速報：和歌山高専で県内企業合同説明会, 近 隣高校生も参加, 7394, p.15, 2010-1-13

\section{著者紹 介}

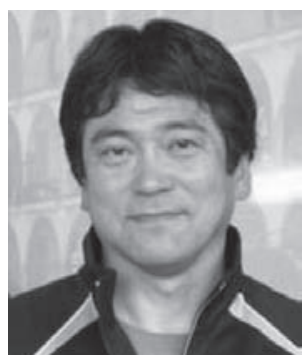

藤本 晶

1972年奈良高専電気工学科卒，卒業と同 時に立石電機(株入社. 1991年和歌山高専 電気工学科助手, 1992年助教授, 1998年 教授. 1995-1996年コーネル大学客員研 究員. 1997-2003年寮務主事, 20032009年教務主事, 2009-2011年副校長, 現在専攻科長.

専門は電子工学, センサ工学. 工学博士. 